九州大学学術情報リポジトリ

Kyushu University Institutional Repository

\title{
Surveillance and Architecture, Analyzing the Idea of Eyes on the Street
}

Fadhila, Syifa

Faculty of Engineering, Universitas Indonesia

Lukito, Nurliani Yulia

Faculty of Engineering, Universitas Indonesia

https://doi.org/10.5109/2740980

出版情報 : Evergreen. 7 (1)，pp.132-137，2020-03. 九州大学グリーンテクノロジー研究教育センター バージョン：

権利関係 : 


\title{
Surveillance and Architecture, Analyzing the Idea of Eyes on the Street
}

\author{
Syifa Fadhila ${ }^{1}$, Yulia Nurliani Lukito, ${ }^{2 *}$ \\ ${ }^{1,2}$ Faculty of Engineering, Universitas Indonesia, Depok, Indonesia \\ E-mail: yulianurliani@yahoo.com
}

(Received November 1, 2019; Revised January 23, 2020; accepted February 24, 2020).

\begin{abstract}
The quality of public space plays a key role for a sustainable city. In a good public space, it is easy for people to see each other and informally take care of the space. This inevitable visibility can be used to improve the quality of public space as Jane Jacob's idea of eyes on the street. In addition to this informal surveillance, local authorities and building owners also create formal surveillance that also includes architectural features. This paper aims to find out the relationship between visibility and formal surveillance, as well as their connection to existing architectural features, that resulted in a sustainable safety mechanism in public space. As a case study is Pasar Baru shopping area located in Central Jakarta that shows the concept of eyes on the street initiated by Jane Jacobs. A number of issues are discussed by linking surveillance with architectural features, how surveillance works in public space, and the effects of surveillance in public space.
\end{abstract}

Keywords: visibility; eyes on the street; surveillance; public space; Pasar Baru

\section{Introduction}

Surveillance in general means a supervision of a person or place by 'watching carefully' and focusing on visibility as the main factor of supervision ${ }^{1}$. Surveillance covers a number of things from observation using basic sensory things like vision, smell, and touch, up to more complex technologies such as the use of computer programs ${ }^{2}$. Discussing about surveillance often relates to the idea of supervision such as giving instructions for supervision ${ }^{3)}$, monitoring for behavior or certain actions, and regulate behavior ${ }^{4}$.

Visibility in space is part of informal surveillance that is connected to both seeing other people and being seen by others without intentionally having a purpose for safeguard ${ }^{5}$. With good space visibility, people who are in a certain location in public space can watch other people but at the same time, they cannot escape from other people's gaze ${ }^{6}$. In other words, they become a part of the spectators in the public space and feel safe in the crowds. With this kind of informal surveillance, a person may have a power to control a space since he has a good visual over the space, but in a certain circumstance, a person may become the one who is visually controlled by other people's gaze. Michel Foucault asserts the idea of a space of surveillance or a space where the visibility of a subject can increase control by applying supervision and sanctions ${ }^{7}$. This condition also means that visibility produces a force that creates pressure for people to act in a certain way or to obey the rules, even when they do not know exactly who watches them and who is actually being watched ${ }^{6}$.

Modern society is known to have a lot of space where the people in it are supervised either for negative or positive reasons, both by human and by something mechanical such as surveillance camera, including within the public space. Public space is one of the examples where visibility becomes dominant that controls behavior of people in $i^{8}{ }^{8}$. In public space, visibility has a function connected to the idea of surveillance with a simple logic of the more people in the streets, the safer they become. Their "eyes on the street" offer informal surveillance of the urban environment and the presence of people on the streets contributes to an atmosphere of safety.

It is not easy for people to avoid not to be seen by others. This inevitable visibility can become a power over space that creates a pressure to act in a certain manner. However, visibility alone cannot guarantee a safety atmosphere because it also relates to other elements in public space such as architectural elements. Physical elements like architecture elements and the connection between private and public play an important role in the safety of the environment. Configuration and spatial design such as buildings shape, orientation and openings are also mentioned as an indicator of eyes on the street ${ }^{9}$. Surveillance in public space, either formal or informal, also requires physical elements and a combination between the two creates a mechanical observation.

To discuss the relation between visibility and architectural elements in public space, this paper discusses 
Pasar Baru shopping area located in Central Jakarta as a case study. Pasar Baru shopping areas is known as one of the oldest shopping areas in Jakarta and generally considered as having both mechanical and nonmechanical surveillance. By analyzing eyes on the street, this paper aims to discuss visibility and safety as one aspect to increase the quality of public space ${ }^{10}$. The argument in this paper is that good visibility and surveillance can create a safety mechanism for people in public that create comfortable and safe atmosphere in public space.

\section{Eyes on the street}

When talking about visibility in public space, Jane Jacobs asserts the idea of informal or natural surveillance that includes how people who live in the neighborhood take part in the surveillance process ${ }^{9)}$. For instance, owners of shops located in front of the street or people who live in the neighborhood have good visibility for pedestrians and people who come to their neighborhood. She calls this mechanism as natural surveillance or eyes on the street. Most of the time people who live in the neighborhood have no intention to watch the street, but they just want to see outside their window and greet their neighbors. It means that pedestrians who walk on the street are being watched by the owner of the shops or the houses in the neighborhood and this kind of natural surveillance makes pedestrians hesitate to do something bad. Human beings always kept an eye on each other and this has both deflected and induced fear ${ }^{11)}$. When those people attracted to each other and open conversation, then interaction occur automatically so that surveillance goes more intense ${ }^{12)}$.

According to Jacobs, a good city environment can be seen from the following three indicators:

1) A clear division between public space and private space.

2) Eyes on the street.

3) A large number of people who see activities on the road in a sustainable manner.

Jacobs also stated that each building must be oriented toward the street to increase supervision, because in this way the occupants of the buildings can see directly activities occur on the street. She says "You cannot make people use streets they have no reason to use. You cannot make people watch streets they do not want to watch" 9). The existence of a living street creates a comfortable atmosphere for people to walk and a sense of safety. One of the existences of space security is because of the visibility. Rather than focusing on crime and victims of criminal acts, to achieve the three good city environment indicators above, Jacobs focused more on people's concern and experience as a community, as well as environmental planning to improve security as a preventive measure. To make a city safe and comfortable to live, it is important to have eyes on the street with a sense of belonging to the environment which comes from a well-divided environment between private and public space.

Feeling safe on the street can work well when people are willing to use the street comfortably and unconsciously participate in monitoring the street. The main requirement in natural surveillance according to Jacobs is when people on the street can have a natural surveillance ${ }^{9}$. Shops, bars, and restaurants are concrete reasons for the streets to remain alive but there must be s'ome different types of businesses to attract people to come. In addition, there are also pathways where people cross the street. With the eyes on the street, it is people who looked at other people and acquire the ability to observe and react as urban life unfolds in front of them.

People such as shopkeepers and visitors are actors in the success of safety and natural surveillance in public space because they have a power to control the environment and create an awareness of supervision in the environment. Moreover, people who are permanent workers in there are familiar with the environment so that they can see activities and recognize changes happen. Another important factor in natural surveillance is good street lighting ${ }^{13)}$. Street lighting are placed to improve visibility and the main objectives of street lighting are to support the safety of pedestrian and traffic especially during the night time ${ }^{14}$. Street lighting can also be solar street light by using solar energy to make the street lighting sustainable 15 ).

\section{Formal surveillance}

Surveillance is based only on visibility but in informal surveillance there is still a gap between people who see and people who are being seen can change the role and sometimes they do not have an intention to take care of their surroundings. In this case, formal surveillance conducted by authorities or shop owners is also needed. Formal surveillance is intended to produce a threat and to prevent perpetrators from actions that are not in accordance with the rules and norms in society. The threat comes from official security personnel such as security guards, police, and the management. With the existence of formal surveillance, people are aware that they are being observed. If they violate the rules of their environment, they will be at risk of being caught and sanctioned for their actions $^{16)}$. In addition, the authorities can also give a positive image as a security function which increases optimism in the environment ${ }^{17)}$.

In the 1950s, eyes on the street was a different phenomenon $^{18)}$. The use of interior and exterior spaces is very different from now. People are more likely to walk and visit relatives by interacting in public places. Children walk to school and play in the street. Whereas today, interior space is much more widely used new technology ${ }^{19)}$. In this digital era, eyes on the street is no longer as effective as the past because some of the role of 
human is replaced by camera. Compared to natural surveillance as in the concept of eyes on the street, the role of mechanical surveillance is more effective when viewed from the way it works. People cannot supervise a situation continuously without missing anything, while mechanical surveillance such as installing CCTV can work 24 hours without missing any event. However, mechanical surveillance cannot follow up if there is a direct deviation while human can act immediately. Both have advantages and disadvantages which if combined will improve surveillance.

\section{Methods}

The methods used in this paper are based on theories from various architectural and urban studies, including literature related to surveillance as a supervision by 'watching carefully' by Michel Foucault and Christopher Dandeker. Theories also include visibility as the main factor of supervision and eyes on the street defined by Jane Jacobs and David Lyon as a good city environment indicators following by a clear division between public space and private space, also a large number of people who see activities on the road in a sustainable manner. Pasar Baru shopping area was chosen because it was considered as having good surveillance in accordance with the focus of this paper. A field research to Pasar Baru was also conducted first as a way to understand the condition of the case study and second to find out the relationship between visibility and formal surveillance. After the observation, we analyze the connection between visibility and existing architectural features in public space that resulted in a sustainable safety mechanism for public space.

\section{Result and discussion}

Pasar Baru is one of the oldest shopping areas in Jakarta which was built in 1820 on Jalan Pasar Baru, Central Jakarta. This area is a place of a mixed culture between Indonesian, Chinese and Indian cultures, making it a special attraction for local and foreign visitors ${ }^{20)}$. Since it was built, land use on Jalan Pasar Baru and its surroundings has been dominated by commercial and residential mix used buildings along the main channel ${ }^{21)}$. Throughout this area, there are various kinds of shops such as clothing, beauty products, and restaurants. Pasar Baru has a straight street with two gates at its ends becomes the main accesses to the shopping area. Each gate is equipped with a portal and a security guard post to control the people who enter Pasar Baru area. During Pasar Baru's operation hours, the portal is open with security guards on duty and when it closes, the portal is lowered and locked by security guards.

In addition, there are also several security guards located almost every eight meters. In carrying out their duties, the guards use official attributes that show their identity so that people are aware of their role as security guards. People are aware of the role of security guards, so it can generate a safety atmosphere and regulate the behavior of people so that it is expected to prevent any deviation in visitor behavior.

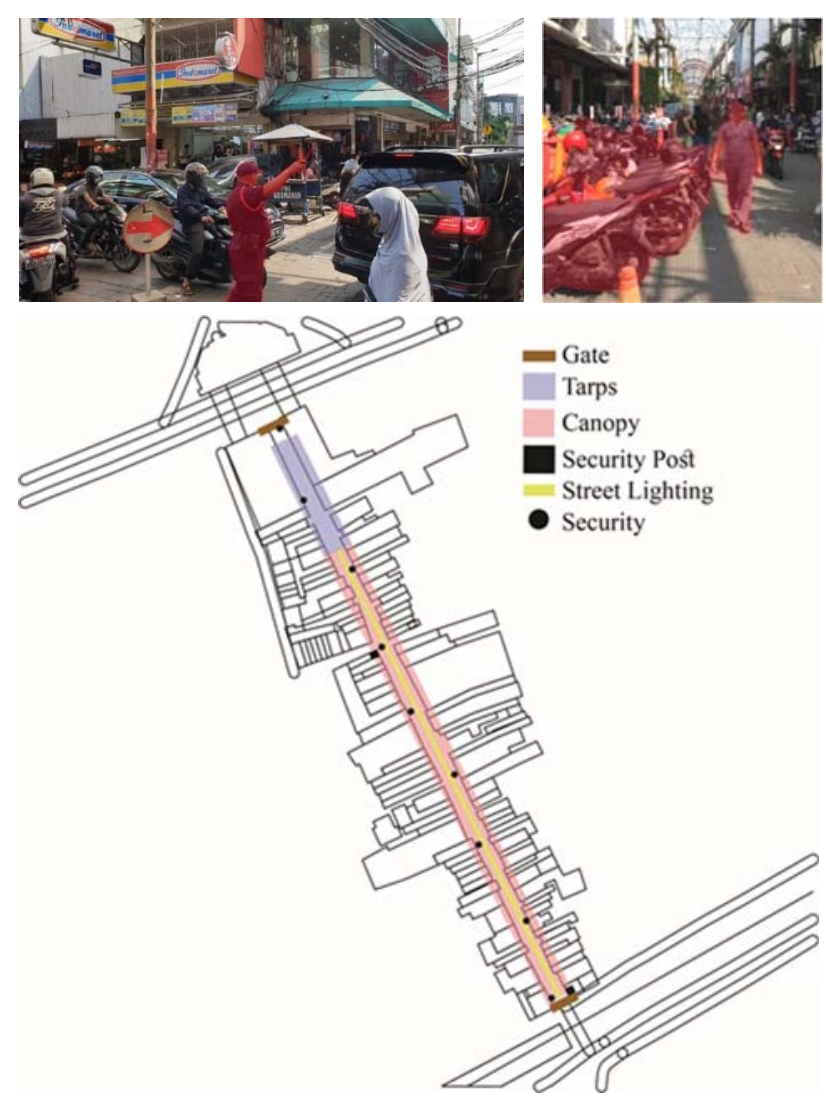

Fig. 1: Pasar Baru with portals, security posts, and parking attendants who manage space in Pasar Baru

Also, there are some parking attendants who arrange vehicles parked in Pasar Baru area. People are aware of the parking attendant from his attributes, and they are active in organizing the vehicle parking in front of the shops with their gestures. The parking attendant also has the power to organize the parking area, so that visitors inevitably obey the parking attendant's instructions. Organizing parking areas is also a form of supervision so that the presence of the parking attendant can prevent a disorder.

Pasar Baru has a straight main street and there are a number of permanent shops, kiosks and also nonpermanent street vendors who use tarps as a top cover and small tables for selling their goods. Street vendors organize their tables close to each other with a three-meter distance located in some places to allow visitors to walk. With such distance, vendors can see other vendors' goods and they usually sit in front of their tables. With this position, vendors can supervise each other. 

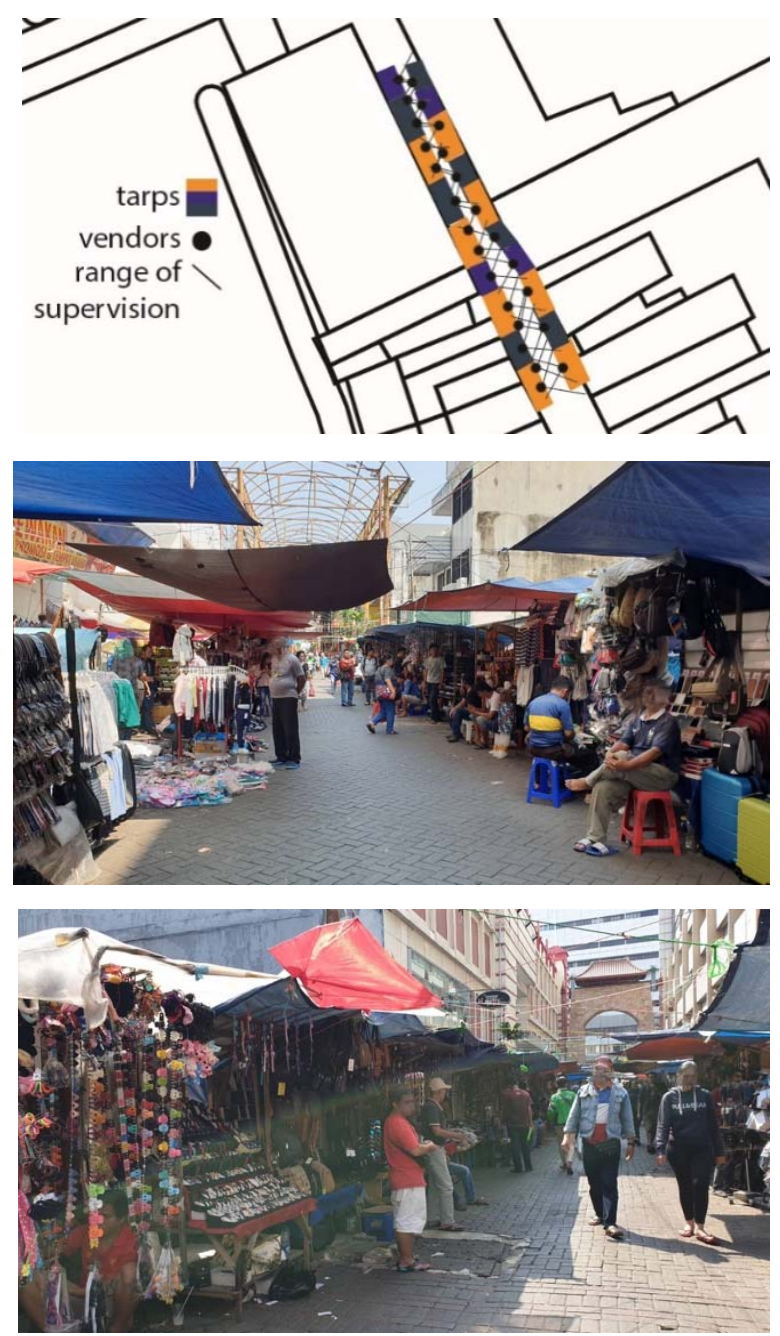

Fig. 2: Street vendors and natural surveillance mechanism

For example, if there is a buyer who wants to buy and the owner of the stuffs is not in the place, other vendors will call the owner or even assists the buyer. From the example above, there is a strong bond among sellers and there is a surveillance mechanism created among vendors. Visitors are aware of the surveillance system of those vendors. Tarps that are exposed to sunlight will create shadows and shadows create a territory, thus creating a range of areas of supervision by vendors towards people passing through their area. The organization of space shows a clear division between public and private space while a large number of people who see activities on the road creates a sustainable surveillance mechanism through eyes on the street. The idea of 'sustainable society' was suggested for the first time in 1980 in the World Conservation Strategy ${ }^{22)}$ of the International Union for Conservation of Nature and Natural Resources (IUCN) ${ }^{23)}$.

There are several other natural surveillance such as the discount basket placed outside the store guarded by shopkeepers who have no special intention to watch people passing by in front of their shops, but because their duties as guardians of discount baskets make them inevitably stand facing the street and become a superintendent on the street by seeing and watching every person who passes. So as to with other staff who distribute flyers; her/his main task is to distribute the flyers to passing by pedestrians but because they are on the road he/she unintentionally becomes a supervisor on the street. Vendors and shopkeepers in the above case according to Eck is called place managers, which indirectly supervise through their job position towards the area ${ }^{24)}$. Unlike the authorities who actually serve as supervisors, supervision is not their job, but become their 'jobs' because they unconsciously carry it out.
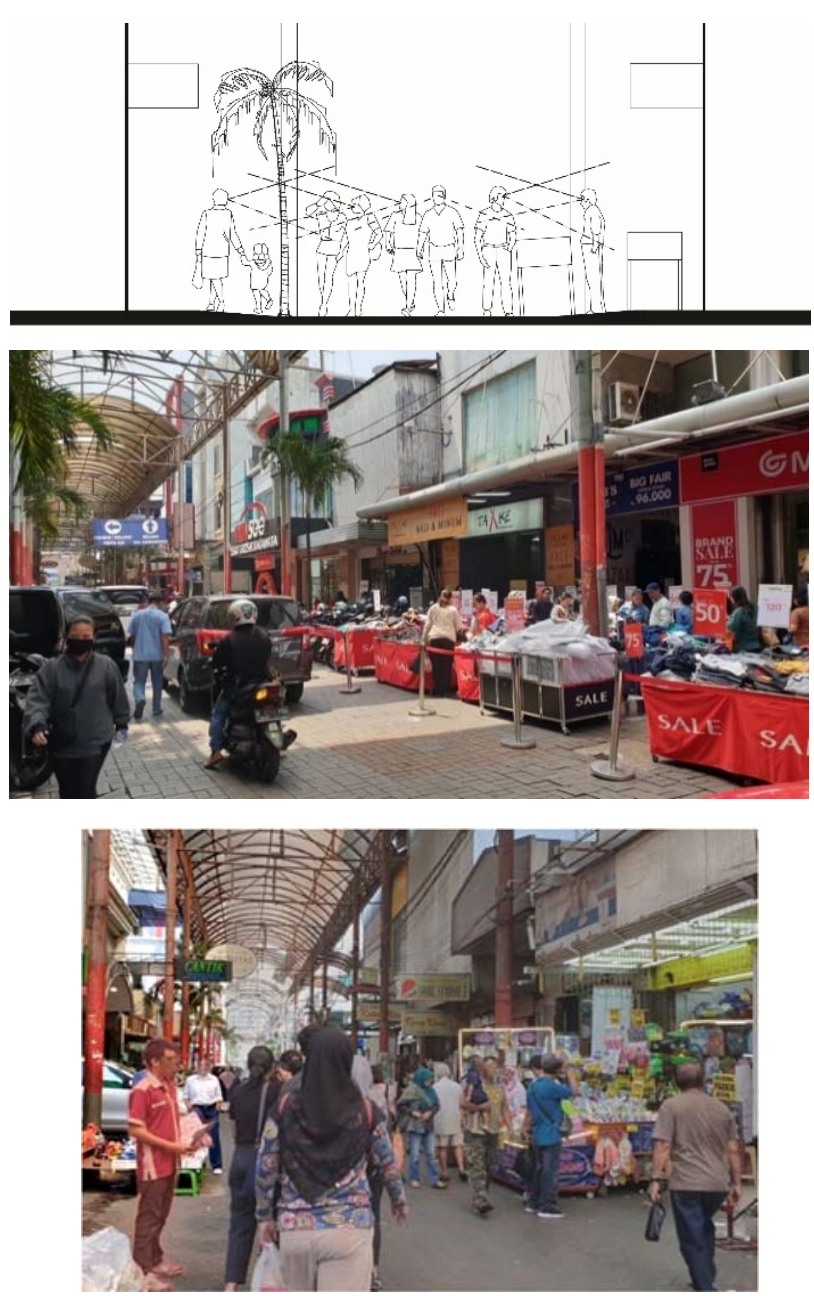

Fig. 3: Shopkeepers, pedestrian, and their mechanism for eyes on the street

At Pasar Baru, the upper part of the pedestrian street is given a canopy so pedestrians are comfortable to walk under it and people voluntarily pass this road. In the other part of the street which is not given a canopy, some vendors take initiative to put tarps above the pedestrian street to cover their stuffs from heat and rain which also protects passing by pedestrians. There are street lighting in each kiosk and on the road, which helps visibility when it is getting dark and improves security. 
From the indicators made by Jane Jacobs as the definition of success of the environment of a city, Pasar Baru applies the presence of eyes on the street with the main actor not only pedestrians but also street vendors, shopkeepers, and the staff who distribute flyers. Those three actors have an important role to play in the eyes of the street as a security function, with their daily trading activities as a cause for knowing well the streets and creating a sense of ownership of the streets in Pasar Baru, resulting in surveillance in a sustainable manner. In addition, along the Pasar Baru street, each building is oriented to the road, thus, increasing space supervision since people who are inside the buildings can see activities occur on the street. In this way, the street becomes alive.

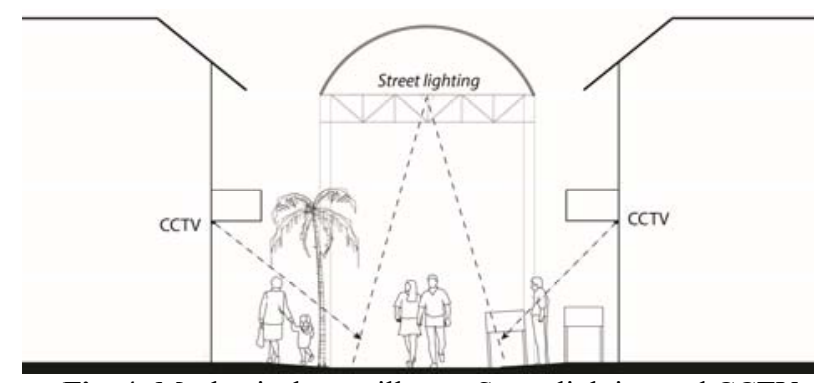

Fig. 4: Mechanical surveillance: Street lighting and CCTV

However, eyes on the street alone does not make the Pasar Baru environment safe, because this mechanism relatively gives limited visibility. Then, there is a hierarchy of streets, such as the main street is located in the middle and pedestrian is located in front of the shops. In front of the shops, street vendors sell their goods which cause the surveillance function with visibility is not enough due to the visibility limitation. There is a need for mechanical surveillance such as CCTV. Minton said that most people like the idea of CCTV and agree that the existence of CCTV will make them feel safer ${ }^{25)}$.

\section{Conclusion}

This paper aims to find out the relationship between visibility and formal surveillance, as well as their connection to existing architectural features that resulted in a sustainable safety mechanism in public space in Pasar Baru shopping area. Pasar Baru applies both formal and informal surveillance. The security guards serve as formal authorities who secure and maintain the orderliness of the environment. Parking attendants -who regulate and maintain the order of the vehicles there serve as informal surveillance. And the role of street vendors and shop keepers - without special actions - also becomes the supervisor of Pasar Baru Street. Those people who have activities in Pasar Baru become what Jacobs mentions as 'eyes on the street' that create a comfortable and safe atmosphere in public space. In addition, the canopy and street lights keep the street alive because they give shadows and lights as well as scale and good visibility for pedestrians. All of those elements produce a 'pressure' that is inevitably making people in the environment obedient because of the power generated by the supervisors. So with this power from eyes on the street, people will be more aware if they want to do unexpected behaviors in the present front of the supervisors due to application of supervision and sanctions to the environment as Michel Foucault calls it a space of surveillance. Pasar Baru uses those elements above as a security function that makes it sustainable in space security.

\section{Acknowledgements}

The research for this paper is conducted as part of a research on architecture and modernity in Indonesia funded by the Ministry of Research, Technology and Higher Education of the Republic of Indonesia under PDUPT Grant \#1671/UN2.R3.1/HKP05.00/2019.

\section{References}

1) Online Etymology Dictionary. Surveillance (n). https://www.etymonline.com/word/surveillance (accessed June 27, 2019).

2) S. Purdy, "Surveillance, Knowledge and Inequality: Understanding Power through Foucault and Beyond," The Hilltop Review, 8 (3) (Iss 1) (2015).

3) C. Dandeker, "Surveillance, Power, and Modernity,". Cambridge, UK: Polity Press, 1994.

4) Gilliom, John, and Monahan, "Supervision, an Introduction to the Surveillance Society,". Chicago: The University of Chicago Press, 2013.

5) S. P. Lab, "Crime Prevention: approaches, practices, and evaluations,". 8 Cincinnati, Ohio: Oxford, 2014.

6) M. Foucault, "Discipline and Punish" the birth of prison,". New York: Pantheon Books, 1977.

7) X. Marquez, "Spaces of Appearance and Spaces of Surveillance," Polity., 44 (1) 6-31 (2012). doi:10.2307/41426920.

8) Z. Bauman, "Post-Modern Ethics,". Oxford: Blackwell, 1994.

9) J. Jacobs, "The Death and Life of Great American Cities,”. New York: Vintage Books, 1961.

10) E. Ravazzoli, and G.P. Torricelli, "Urban mobility and public space. A challenge for the sustainable liveable city of the future," The Journal of Public Space, 2 (2) 37-50 (2017). doi:10.5204/jps.v2i2.9.

11) D. Lyon, "Surveillance Society: Monitoring Everyday Life,". Philadelphia: Open University Press, 2001.

12) Gibran, "Surveillance dalam Ruang Publik,". Depok, 2008.

13) O. Newman, "Defensible Space: Crime Prevention Through Urban Design,". New York: Macmillan, 1972.

14) B.C. Welsh, and D.P. Farrington, "Effects of improved street lighting on crime,". Campbell Systematic Reviews, 2008. doi:10.4073/csr.2008.13. 
15) K. Marzia, M. F. Hasan, T. Miyazaki, and B.B. Saha, "Key Factors of Solar Energy Progress in Bangladesh until 2017," Evergreen, 5 (2) 78-85 (2018). doi:10.5109/1936220.

16) S. Kajalo, and A. Lindblom, "The role of formal and informal surveillance in creating a safe and entertaining retail environment," Facilities., 34 (Iss 3/4) 219-232 (2016).

17) B.C Welsh, M.E. Mudge, and D.P. Farrington, "Reconceptualizing public area surveillance and crime prevention: security guards, place managers and defensible space," Security Journal., 23 (4) 299-319 (2009).

18) M. Felson, "Routine Activities and Crime Prevention in the Developing Metropolis,". Criminology., 25 (1987).

19) S. Moores, "Media and Everyday Life in Modern Society,". Edinburgh: Edinburgh University Press, 2000.

20) "Jakpost guide to Pasar Baru," 2017. https://www.thejakartapost.com/travel/2017/04/23/ja kpost-guide-to-pasar-baru.html (accessed May 25, 2019).

21) L. Kurnia, "Pasar Baru: Colonial Space and Contemporary Hibridity,". Inter-Asia Cultural Studies Journal, Taylor and Francis (2011).

22) International Union for Conservation of Nature and Natural Resources (IUCN), "World Conservation Strategy," (1980).

23) T. Sato, "How is Sustainable Society Established? : A Case Study of Cities in Japan and Germany," Evergreen, 3 (2) 25-35 (2016). doi:10.5109/1800869.

24) J.E. Eck, "A General Model of the Geography of Illicit Retail Marketplaces. In: D. Weisburd and J.E. Eck (eds.)," Crime and Place. Crime Prevention Studies, 4, New York: Monsey Criminal Justice Press (1995).

25) A. Minton, "Ground Control, Fear and Happiness in the Twenty-First Century City," London: Penguin Books, 2009. 